\title{
Causes and Consequences of Rapid Erosion of Cultural Values in a Traditional African Society
}

\author{
E. O. Wahab, S. O. Odunsi, and O. E. Ajiboye \\ Department of Sociology, Lagos State University, PMB 1087, Lagos State, Nigeria \\ Correspondence should be addressed to E. O. Wahab, eliasphd@yahoo.com
}

Received 9 December 2011; Revised 9 February 2012; Accepted 10 February 2012

Academic Editor: Kaushik Bose

Copyright () 2012 E. O. Wahab et al. This is an open access article distributed under the Creative Commons Attribution License, which permits unrestricted use, distribution, and reproduction in any medium, provided the original work is properly cited.

The culture of a people is their identity as it affords them due recognition. This paper therefore is aimed at examining the causes and consequences of rapid erosion of cultural values in nigeria. Social change theory was used in this paper. This study was carried out in ado-odo/ota lga, with a sample size of 203. Simple statistics like frequency distribution, percentile were used. Chi-square statistics was used in testing the hypotheses. The study found out that there is a positive relationship between social forces such as colonialism, westernization and erosion of cultural values. Also, it was found that there is a positive relationship between the local family structure and the foreign culture. The study concludes that forceful imposition of foreign culture should be discouraged.

\section{Introduction}

In sub-Saharan Africa, people and culture are inseparable since there is no denial of the fact that what makes any human society is its culture; a Latin word which was derived from "colore" meaning to practice or cherish. For a society to be societal it must be cultural; therefore, society and culture are also intertwined. In the same vein, going by the theory of environmental determinism, the culture of any society is largely dictated by its geography. Put another way, there is conspicuous sociological interplay among the concepts of culture, nurture, and nature.

Further when mirrored with sociological panorama, both the macro- and micro-sociological tentacles, which subsume the entirety of social institutions, are determined by culture; an all-including sociological and anthropological concept that is ineluctable for the existence and functionality of any social group. Linton [1] states that "the culture of a society is the way of life of its members; the collection of ideas and habits which they learn share and transmit from generation to generation." Indeed, "culture is a design for living held by; members of a particular society" [2].

The culture of a people is their identity as it affords them due recognition. It is their underlying distinguishing factor from other peoples and cultures. In fact, all societies across the globe have various and divergent cultures which they cherish and practice. Nevertheless, no two cultures, when juxtaposed are absolutely identical as attested to by ethnographers. In order for a society to operate functionally and effectively, they must ensure and maintain strict and constant adherence to the various components of their culture.

If, as Tylor [3] asserted, "culture is that complex whole which includes knowledge, belief, arts, morals, customs, laws and other capabilities which are learned, shared by men as members of society, and transmitted from one generation to another." Any laxity, lassitude, and levity exhibited by its custodians would result in rapid erosion and disappearance of the uniqueness of the people and their culture. Since the genesis of culture, is as old as man himself, without it, man is reduced to an animal. Culture therefore has two essential qualities: first, it is learned and second, it is shared.

Sociologically, many activities of members of any society such as eating, music, dancing, occupation, education (formal, informal, and nonformal), visiting friends, courtship, marriage (its forms and types), beliefs (festivals and liturgies), naming and burial ceremonies, entertaining friends and guests, greetings, and system of government, are all found within the confine of nonmaterial culture which is the exclusive preserve and concern of this study. Material 
aspect of culture which comprises the physical and touchable implements or objects such as wears, computer, spoon, pot, cup, cutlass, building, phone, and sandal, is also invaluable and complementary.

The renowned anthropologist Murdock [4] has produced an itemized list of cultural traits that he claims has universal application. Included among the eighty-eight general categories of behaviour are such practices as behavioural patterns of cleanliness training, food taboos, and funeral rites; such principles of social organization as property rights, religious practices, and kinship arrangements, such practical knowledge as fire making, the use of tools and names for different plants. It is important to keep in mind that at no point do cultural universals carry down to the actual details of what people say and do [5]. It is the formsthe broad types of "behavior" - and not the specific contents of behaviour that are found in all cultures.

Culture is essential to our humanness. It contains a set of readymade definitions each of us reshapes very little in dealing with social situations. In other words, culture provides a kind of blueprint or map for relating with others. Consider how you find your way in social life. How do you know how to act in a gathering, with a stranger, in a funeral, naming ceremony, toward a person who smiles, leers or swears at you? Your culture supplies you with broad, standardized, prefabricated answers, and formulas or recipes for dealing with each of these situations. Not surprisingly, if we know a person's culture, we can understand and even predict a good deal of his or her behaviour. The need for this research arose due to the unbridled increase in disappearance of cultural values among the Aworis in Ado-Odo/Ota Local Government Area (LGA) Ogun State. Thus, to unravel the causes and consequences of the eroding significant cultural values among the Aworis in Ado-Odo/Ota LGA, Ogun State, certain clearcut questions have to be provided answers to. For instance, what language do you understand or speak best? How many languages do you speak or understand? How many native attires do you have compared with the English wears?

\section{Theoretical Orientation}

Theory is a set of interrelated ideas or proposition on a social phenomenon, and it is used to describe tested and untested ideas. In other words, theory generally refers to the summary of knowledge in the subject field arranged in interrelated statement.

Based on this, theory of social change was used to explain the rapid erosion of cultural values.

\section{Social Change Theory}

Odetola [6] see "social change as primary change in social relation." Succinctly put, social change means change in social structure, within the framework of such structural changes, in social institutions.

Basic institutions perform function for the society, thus these basic institutions are dynamic and adaptive to changes. It should be noted that the environment of social structure requires certain amount of persistence in some of their features in order to perform that expected function. But observations portray that society and indeed components of social structure change continuously though often imperceptibly. Social change could either bring about progress for the members of a society or visit them with retrogression. As human beings collectively adapt themselves to their environment, they bring about changes to their ways of life.

But for the purpose of the status quo, we are concerned about the changes that transform the fabric of our culture occasion our forgotten values day in day out. The applicability of this theory is that it has strongly affected the ways of doing things in all societies. The urbanization and industrialization have altered the totality of our social institutions, not living the political and economic systems unaffected. The Nuclearization of the family has also negatively touched the socialization and internalization processes.

In a nutshell, the factors responsible for social change have brought about major changes in the traditional-tomodern society. Since change is inevitable, cultural dynamics of any society cannot be foreclosed be it in form of cultural accumulation, that is, addition of new traits to the already existing ones or cultural reduction, or cultural diffusion which is infusion of new cultural traits. All this can still be in a way checkmated.

\section{Methods and Materials}

The area in which the study was carried out is Ado-Odo/Ota LGA. The study area happens to be one of the twenty (20) local government areas in Ogun State, while Ogun State is one of the thirty-six (36) states in the federation with its capital, Abeokuta. Myriad of cultural groups with different dialects among the Yoruba's other than the Aworis, such as the Egbas, Ijebus, Yewas, Ondos, and Oyos are equally traceable in the geographical settlement.

Further, the local government area houses are virtually a representative from all the over 350 ethnic groups in Nigeria such as the Hausas, Igbo, Fulani, Itshekiri, Urhobo, Nupe, and Efik, who have mingled with and peradventure married the autochthons or the Aborigines.

The study population is not without their occupations. Predominantly, majority of the people opt, for farming and trading as dictated and determined by their geography. It is expedient to assert therefore that colonialism, Western Education or Westernization and industrialization have transformed the circumstance as we now have civil servants, company and factory workers, and those working in other private and public establishments. An explanatory survey design has been employed to provide a relatively detailed account of the working of a phenomenon under conditions. It is aimed at explicating, in some detail, the characteristics of a large and homogenous population of a sample of that population. And to answer questions of the type "why" and "how" so as to primarily learn more about the given situation, and therefore facts and information are gathered to form the basis of increase understanding. Six (6) houses were sampled from every one of the six (6) streets in the two (2) Awori communities, where six (6) questionnaires were 
TABLE 1: Sociodemographic characteristics of the respondents.

\begin{tabular}{|c|c|c|c|c|}
\hline $\mathrm{S} / \mathrm{N}$ & Characteristics & Variables & Frequency & Percentage \\
\hline \multirow{3}{*}{1} & \multirow{2}{*}{ Sex } & Male & 119 & 58.62 \\
\hline & & Female & 84 & 41.38 \\
\hline & \multirow{4}{*}{ Religion } & Total & 203 & 100 \\
\hline \multirow{4}{*}{2} & & Islam & 122 & 60.10 \\
\hline & & Christianity & 75 & 36.95 \\
\hline & & ATR & 6 & 2.95 \\
\hline & & Total & 203 & 100 \\
\hline \multirow{6}{*}{3} & \multirow{6}{*}{ Age } & $20-24$ & 71 & 34.98 \\
\hline & & $25-29$ & 56 & 27.59 \\
\hline & & $30-34$ & 30 & 14.78 \\
\hline & & $35-39$ & 24 & 11.83 \\
\hline & & 40 and above & 22 & 10.83 \\
\hline & & Total & 203 & 100 \\
\hline \multirow{5}{*}{4} & \multirow{4}{*}{ Marital status } & Married & 68 & 33.50 \\
\hline & & Single & 95 & 46.80 \\
\hline & & Separated & 13 & 6.40 \\
\hline & & Divorced & 27 & 13.30 \\
\hline & \multirow{7}{*}{$\begin{array}{c}\text { Educational } \\
\text { status }\end{array}$} & Total & 203 & 100 \\
\hline \multirow{6}{*}{5} & & Primary & 30 & 14.78 \\
\hline & & SSCE/WASSCE & 88 & 43.35 \\
\hline & & NCE/OND & 42 & 20.69 \\
\hline & & BSC/HND & 27 & 13.30 \\
\hline & & Others & 16 & 7.88 \\
\hline & & Total & 203 & 100 \\
\hline \multirow{4}{*}{6} & \multirow{4}{*}{ Type of family } & Monogamy & 79 & 38.92 \\
\hline & & Polygamy & 124 & 61.08 \\
\hline & & Others & - & - \\
\hline & & Total & 203 & 100 \\
\hline
\end{tabular}

distributed for respondents in each house. This implies that in each community, 108 questionnaires were administered. The questionnaires were distributed for males and females alike so as to be gender sensitive and to forestall bias which could be inimical to the research outcome. In all, a total of 216 questionnaires were administered.

For the purpose of this study, structured questionnaire (quantitative technique) has been chosen. Preference was given to it as it facilitated easier analysis and interpretation of responses to the questions asked. Simple statistical tools such as simple percentage and chi-square have been adopted for data interpretation and test of hypothesis. Using the chi-square to test the null hypotheses against the data collected.

\section{Results}

5.1. Introduction. Attempts were made to present all facts and information regarding the study, and it focuses on the analysis of quantitative data. In the presentation, an attempt was made to use the simple percentage analysis at first, with its total percentage of all facts and information put at hundred. In the analysis, the cross-analysis of chi-square method of testing hypothesis was used. This will include both dependent and independent variables.

With regard to the sex, about three-fifth are males, while the remaining two-fifth are females.

In terms of religious affiliation, more than half of the sampled respondents are Muslims, while the remaining two-fifth was shared between Christianity and the African traditional religion (ATR). As portrayed by age distribution, about two-fifth of the respondents fall within the age bracket 20-24, while the remaining three-fifth was shared by other age brackets.

Close to half of the population, as regards marital status, are single, while the rest of the statuses hold on to the remaining percentage. As revealed by educational status, less than half of the respondents possess SSCE/WASSCE certificate, while the remaining figure goes for monogamy. No other type of marriage was being practiced.

In terms of whether colonialism is responsible for erosion of cultural values, more than three-fifth responded "yes" while the remaining less than two-fifth was paired by other two variables.

As regards responses on whether one who is opportune to travel abroad would still return even if the situation is still not encouraging, about two-fifth opted for "yes", while the remaining three-fifth went for "I do not know" and "no" variables.

Regarding the characteristic that asks whether foreign culture is better than, yours, close to two-fifth of the respondents went for "yes", while the remaining three-fifth go for the other two variables.

In terms of the seeming indifference of the Aworis in promoting their cultural values, more than two-fifth responded YES, while the remaining figure was paired by the rest of the variables.

Concerning whether the family structure has been improved by the foreign culture, more than half of the respondents opted for NO, while the remaining variables shared by the rest less than half percentage.

With regard to whether western education as a foreign culture has done us good than bad, about three-fifth of the population opted for "yes", while the remaining close to twofifth was shared between the other two variables.

Concerning the question of whether the culture is safe from destruction in the nearest future, about two-fifth responded "no", while the remaining figure was paired by the other two variables.

On the question of whether the Aworis have lost much significant cultural values significant cultural values than they have benefited from the foreign cultures; about threefifth of the population responded yes, while the remaining two-fifth went for the remaining variables.

In terms of whether it affect ones being an Awori even if all the cultural values are eroded, close to half of the population responded "yes", while the remaining percentage go for the other variables.

With regard to the type of medical care one always go for, half of the population responded that they always opt 
TABLE 2: Causes of erosion of cultural values.

\begin{tabular}{|c|c|c|c|c|}
\hline $\mathrm{S} / \mathrm{N}$ & Characteristics & Variables & Frequency & Percentage \\
\hline \multirow{4}{*}{7} & \multirow{3}{*}{$\begin{array}{l}\text { Is colonialism responsible for cultural } \\
\text { values erosion? }\end{array}$} & Yes & 150 & 73.89 \\
\hline & & I do not know & 20 & 9.85 \\
\hline & & No & 33 & 16.26 \\
\hline & & Total & 203 & 100 \\
\hline \multirow{4}{*}{8} & \multirow{4}{*}{$\begin{array}{l}\text { If you are opportune to travel abroad, } \\
\text { would you still come back even if the } \\
\text { situation is still not encouraging? }\end{array}$} & Yes & 98 & 48.28 \\
\hline & & I do not know & 24 & 11.82 \\
\hline & & No & 81 & 39.90 \\
\hline & & Total & 203 & 100 \\
\hline \multirow{4}{*}{9} & \multirow{3}{*}{$\begin{array}{l}\text { Do you think that foreign culture is better } \\
\text { than yours? }\end{array}$} & Yes & 46 & 22.66 \\
\hline & & I do not know & 16 & 7.88 \\
\hline & & No & 141 & 69.46 \\
\hline & & Total & 203 & 100 \\
\hline \multirow{4}{*}{10} & \multirow{4}{*}{$\begin{array}{l}\text { The Aworis in schools does not seem to } \\
\text { be interested in promoting their cultural } \\
\text { values }\end{array}$} & Yes & 107 & 52.71 \\
\hline & & I do not know & 18 & 8.89 \\
\hline & & No & 78 & 38.42 \\
\hline & & Total & 203 & 100 \\
\hline \multirow{4}{*}{11} & \multirow{3}{*}{$\begin{array}{l}\text { Has the family structure been improved } \\
\text { by the foreign culture? }\end{array}$} & Yes & 91 & 44.83 \\
\hline & & I do not know & 6 & 2.95 \\
\hline & & No & 106 & 52.22 \\
\hline & & Total & 203 & 100 \\
\hline
\end{tabular}

for orthodox medical care, while the remaining half are for traditional and other types of medical care.

On the question of whether virginity must be protected until after marriage, over four-fifth of the respondents opted for YES, while the remaining percentage do not seem to encourage it.

As regards who is to blame for the forgotten values, less than two-fifth of the population blamed it on the individuals, while the remaining percentage think that other variables should shoulder it.

Concerning whether it is advisable for the Awori indigenes in schools to be taught in Yoruba rather than English, more than half of the respondents do not encourage it, thereby responded "no", while the remaining percentage was shared by the other variables.

Lastly in terms of whether there is any effective way to prevent the culture from vanishing, about four-fifth responded YES, while the remaining one-fifth do not see any way out.

This implies that the majority still believe that despite the observed adverse effects wrought by the social forces that are telling on our cultural values, all hope is not lost if individuals and concerned agencies can discharge their accorded responsibilities.

\subsection{Test of Hypotheses}

\section{Hypothesis 1.}

Ho: there is negative relationship between social forces such as colonialism, westernization, and erosion of cultural values;
HA: there is positive relationship between forces such as colonialism, westernization, and erosion of cultural values.

In $X^{2}$ distribution, when $X^{2}$ cal. $>X^{2}$ tab. We reject Ho and accept HA and vise versa.

The degree of freedom $=(C-1)(R-1)$

$$
\begin{aligned}
\text { DF } & =(2-1)(3-1) \\
& =(1)(2) .
\end{aligned}
$$

Under 0.05 (i.e., 5\%) significant level = 5.99:

$$
X^{2} \text { cal. }=\sum(0-e)^{2}=24.94 .
$$

The decision rule says:

$$
\begin{aligned}
& \text { If } X^{2} \text { cal }>X^{2} \mathrm{Tab} \text {-reject Ho. } \\
& \text { If } X^{2} \text { cal }<X^{2} \mathrm{Tab} \text {-accept HA. }
\end{aligned}
$$

From the Tables 1, 2, 3, 4, and 5, since $X^{2}$ calculated (i.e., 24.94) is greater than $X^{2}$ tabulated (i.e., 5.99), we therefore reject Ho and accept the (alternative hypothesis) HA which states that there is positive relationship between social forces such as colonialism, westernization, and erosion of cultural values.

\section{Hypothesis 2.}

Ho: there is negative relationship between the local family structure and foreign culture;

HA: there is positive relationship between the local family structure and foreign culture. 
TABLE 3: Consequences of erosion of cultural values.

\begin{tabular}{|c|c|c|c|c|}
\hline $\mathrm{S} / \mathrm{N}$ & Characteristics & Variables & Frequency & Percentage \\
\hline \multirow{3}{*}{12} & \multirow{3}{*}{$\begin{array}{l}\text { Western education, as a foreign culture, } \\
\text { has done more good than bad to us. }\end{array}$} & Yes & 119 & 58.62 \\
\hline & & I do not know & 14 & 6.90 \\
\hline & & No & 70 & 34.48 \\
\hline & & Total & 203 & 100 \\
\hline \multirow{4}{*}{13} & \multirow{3}{*}{$\begin{array}{l}\text { Do you think your culture is safe from } \\
\text { destruction in the nearest future? }\end{array}$} & Yes & 76 & 37.44 \\
\hline & & I do not know & 38 & 18.72 \\
\hline & & No & 89 & 43.84 \\
\hline & & Total & 203 & 100 \\
\hline \multirow{4}{*}{14} & \multirow{4}{*}{$\begin{array}{l}\text { The Aworis have lost much significant } \\
\text { cultural values than they have benefited } \\
\text { from foreign cultures }\end{array}$} & Yes & 120 & 59.11 \\
\hline & & I do not know & 14 & 6.90 \\
\hline & & No & 69 & 33.99 \\
\hline & & Total & 203 & 100 \\
\hline \multirow{4}{*}{15} & \multirow{3}{*}{$\begin{array}{l}\text { Does it affect you being an Awori even if } \\
\text { all your cultural values are eroded? }\end{array}$} & Yes & 98 & 48.27 \\
\hline & & I do not know & 18 & 8.87 \\
\hline & & No & 87 & 42.86 \\
\hline & & Total & 203 & 100 \\
\hline \multirow{5}{*}{16} & \multirow{3}{*}{$\begin{array}{l}\text { Which type of medical care do you always } \\
\text { go for? }\end{array}$} & Orthodox & 84 & 41.38 \\
\hline & & Traditional & 102 & 50.25 \\
\hline & & I do not know & 17 & 8.37 \\
\hline & & Total & 203 & 100 \\
\hline & & Yes & 65 & 32.02 \\
\hline \multirow[t]{4}{*}{17} & Is democracy better than monarchy? & I do not know & 11 & 5.42 \\
\hline & & No & 127 & 62.56 \\
\hline & & Total & 203 & 100 \\
\hline & & Classic & 51 & 25.12 \\
\hline \multirow[t]{3}{*}{18} & What type of music do you like best? & Fuji & 75 & 36.95 \\
\hline & & Others & 77 & 37.93 \\
\hline & & Total & 203 & 100 \\
\hline
\end{tabular}

TABLE 4: Recommendations.

\begin{tabular}{|c|c|c|c|c|}
\hline $\mathrm{S} / \mathrm{N}$ & Characteristics & Variables & Frequency & Percentage \\
\hline \multirow{4}{*}{19} & \multirow{4}{*}{ Must virginity be protected until after marriage? } & Yes & 171 & 84.24 \\
\hline & & I do not know & 6 & 2.96 \\
\hline & & No & 26 & 12.80 \\
\hline & & Total & 203 & 100 \\
\hline \multirow{5}{*}{20} & \multirow{4}{*}{ Who is to blame for our forgotten values? } & Government & 43 & 21.18 \\
\hline & & Individuals & 69 & 33.99 \\
\hline & & Col. masters & 56 & 27.59 \\
\hline & & Predecessors & 35 & 17.24 \\
\hline & & Total & 203 & 100 \\
\hline \multirow{5}{*}{21} & \multirow{3}{*}{$\begin{array}{l}\text { Do you advise that the Awori indigenes in schools } \\
\text { be taught in Yoruba rather than English? }\end{array}$} & Yes & 72 & 35.47 \\
\hline & & I do not know & 18 & 8.86 \\
\hline & & No & 113 & 55.67 \\
\hline & & Total & 203 & 100 \\
\hline & & Yes & 162 & 79.80 \\
\hline \multirow[t]{3}{*}{22} & Is there any effective way to protect our culture? & I do not know & 7 & 3.45 \\
\hline & & No & 34 & 16.75 \\
\hline & & Total & 203 & 100 \\
\hline
\end{tabular}


TABLE 5: Contingency table.

\begin{tabular}{lccc}
\hline Variables & Male & Female & Total \\
\hline Yes & 102 & 48 & 150 \\
No & 7 & 26 & 33 \\
I do not know & 10 & 10 & 20 \\
\hline Total & 119 & 84 & 203 \\
\hline
\end{tabular}

The degree of freedom $=(C-1)(R-1)$,

$$
\begin{aligned}
\mathrm{DF} & =(2-1)(3-1) \\
& =(1)(2) \\
& =2 .
\end{aligned}
$$

Notably, 2 under 0.05 (i.e., 5\%) significant level = 5.99:

$$
X^{2} \text { cal. }=\left(\frac{0-e}{e}\right)^{2}=7.78
$$

The decision rule says

$$
\begin{aligned}
& \text { If } X^{2} \text { cal }>X^{2} \text { tab.-reject Ho and } \\
& \text { If } X^{2} \text { cal }<X^{2} \text { tab.- - accept HA. }
\end{aligned}
$$

From the Table 6, since $X^{2}$ cal. (i.e., 7.78) is greater than $X^{2}$ tab. (i.e., 5.99); we therefore reject $\mathrm{HO}$ and accept HA which says there is positive relationship between the local family structure and the foreign culture.

\section{Conclusion}

The ease and frequency with which people move around the world, and improvements in communications and the global marketing of styles, places and images can lead to a cultural supermarket effect. People are no longer confined to developing identity based upon the place in which they live, but can choose from a wide range of different identities. They now adopt clothes, ways of speaking, values, and lifestyles of any group of their choice.

Adherence to the pristine purity and unadulterated cultural traits, values and virtues of peoples and places are not the same. It is rapidly constant in the urban setups, while the plague of cultural values erosion is somewhat vehemently resisted, and the values consciously internalized in purely rural areas. However, this does not suggest that there are no communities that are paired by urbanism and ruralism.

What we have lost is the organic community with the living culture it embodied. Folk songs, folk dances, Cotswold cottages, handicraft products, and virginity among others are signs of something more; an art of life, a way of living, ordered and patterned involving social arts, codes of intercourse and a responsive adjustment, growing art of immemorial experience, to the natural environment and the rhythm of the year.

Disdain or pity for African traditional lifestyle equated with a "deprived" upbringing is etched into the very
TABLE 6: Contingency table.

\begin{tabular}{lccc}
\hline Variables & Male & Female & Total \\
\hline Yes & 71 & 20 & 91 \\
No & 63 & 43 & 106 \\
I do not know & 4 & 2 & 6 \\
\hline Total & 138 & 65 & 203 \\
\hline
\end{tabular}

legislation of social service delivery in the United States which abruptly cuts off benefits to those who do not hide their traditional west African family relationships from the view of neoliberal warfare bureaucrats. The US social service system actively legislates against west African cultural coping mechanisms [7]. Africans' epistemic and cultural advantages remain suppressed under the influence of global stereotype, which are reinforced through mainstream media.

Lastly, the cultural values scenario in Nigeria is not far from the theatre, where western education is a tool that is constantly and consistently reshaping the psyche and mentality of the people, especially the educated fellows.

\section{Recommendations}

One reason people differ in their behaviour is that they have different cultures. Culture reflects the ideas and meanings we share and everything that is human made. In evolutionary terms, culture gives us a tremendous vantage over all other organism. It is our social legacy.

To ensure fulfillment of the above, one would, first and foremost, recommend that, on the level of individuals, everyone who is attached to any culture be culturally conscious and alerted to his or her identity and its uniqueness. In other words, culture is inseparable from people and should therefore be cherished and relished.

Further, the social institutions such as the family which shoulders the responsibility of procreation and orientation of new ones should not be loose in its function of socialization, the agents of which should be closely monitored. Rather, they should be made to internalize the values and virtues, which are in tandem with the family's cultural dictates so as to ensure behavioural sameness and ideological similarity.

On the part of the government, political power should be utilized to encourage cultural peoples, regardless of their tribal divergence, to develop interest in promoting and market their cultural uniqueness and potency, which could be of socioeconomic advantage. This is to bring to bear the maxim that "there is unity in diversity." Nothing makes the diversity other than culture. In other words, every culture has its own peculiarities and idiosyncrasies that make it stand out. Also, students whose priority is African languages study should be put on scholarship.

Finally, it can be unarguably stated that no culture is better than another. The so-called superior or dominant ones on the global scene are only fortunate. Forceful imposition of a people's cultural lifestyle on another is strongly discouraged in the light of cultural relativism. 


\section{References}

[1] R. Linton, Present World Conditions in Cultural Perspective, Columbia University Press, New York, NY, USA, 1945.

[2] C. Kluckhorn, Mirror for Man, Greenwich, Conn, USA, 1951.

[3] E. Tylor, Culture, Signet, New York, NY, USA, 1871.

[4] G. P. Murdock, Social Structure, Free press, New York, NY, USA, 1950.

[5] J. Snarey, A Question of Morality, 1987.

[6] P. O. Odetola, Nigerian Heritage, Heinemann, Ibadan, Nigeria, 1978.

[7] H. Lauer, "Rethinking "tradition versus modernity": the social construction of the "HIV/AIDS crisis" in Africa," Culture Today Journal, vol. 7, no. 1, pp. 2-13, 2006. 


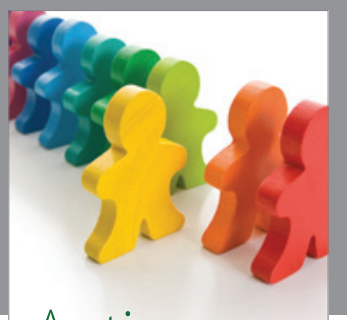

Autism

Research and Treatment
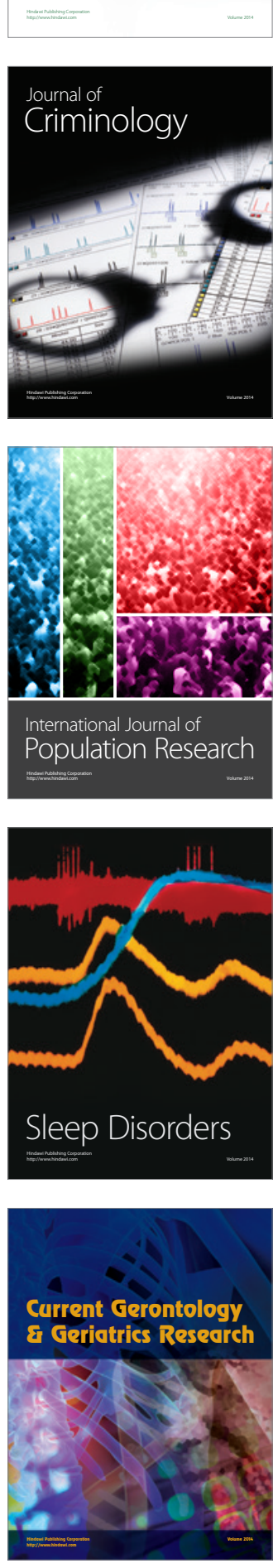
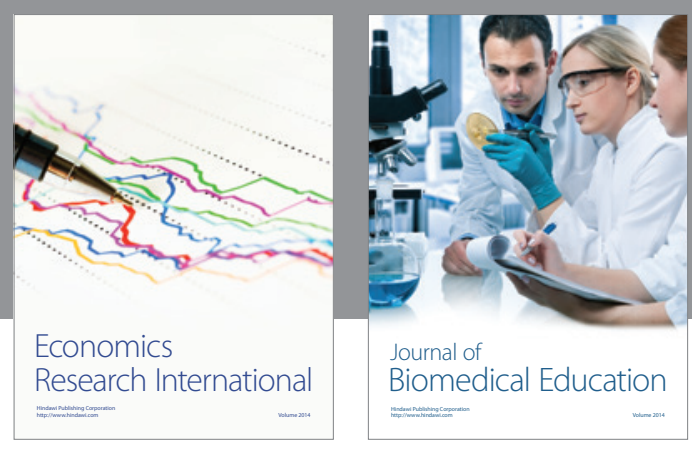

Journal of

Biomedical Education

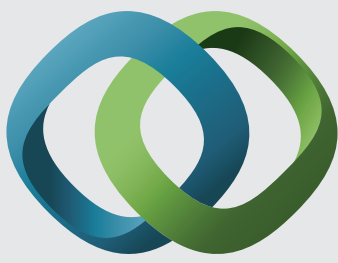

\section{Hindawi}

Submit your manuscripts at

http://www.hindawi.com
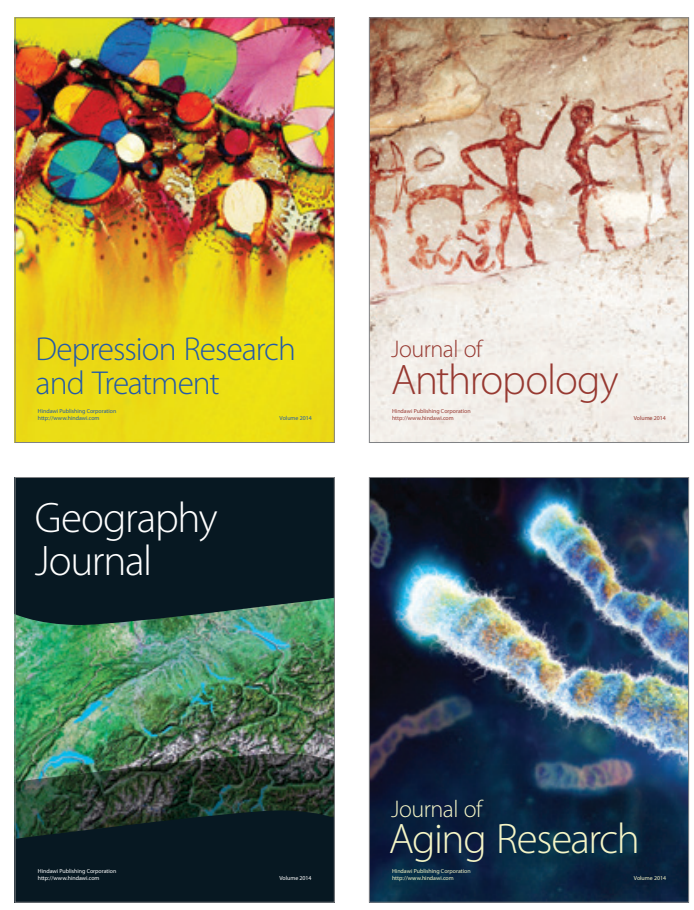

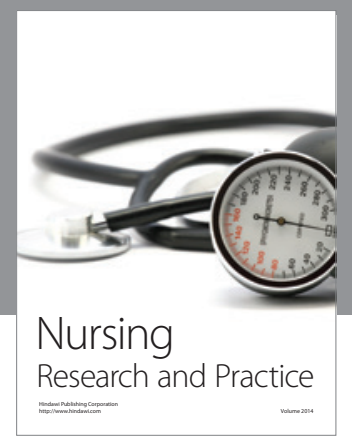

Nursing

Research and Practice

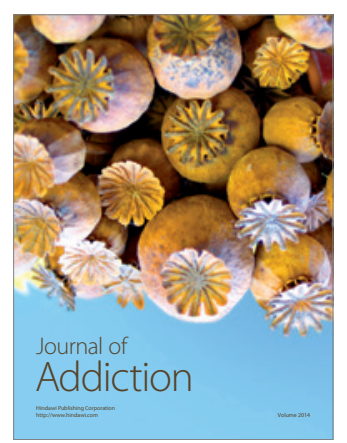

Child Development

Research

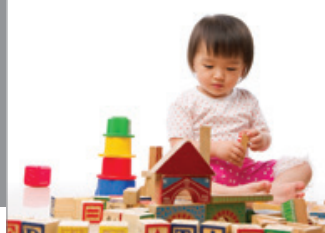

迥
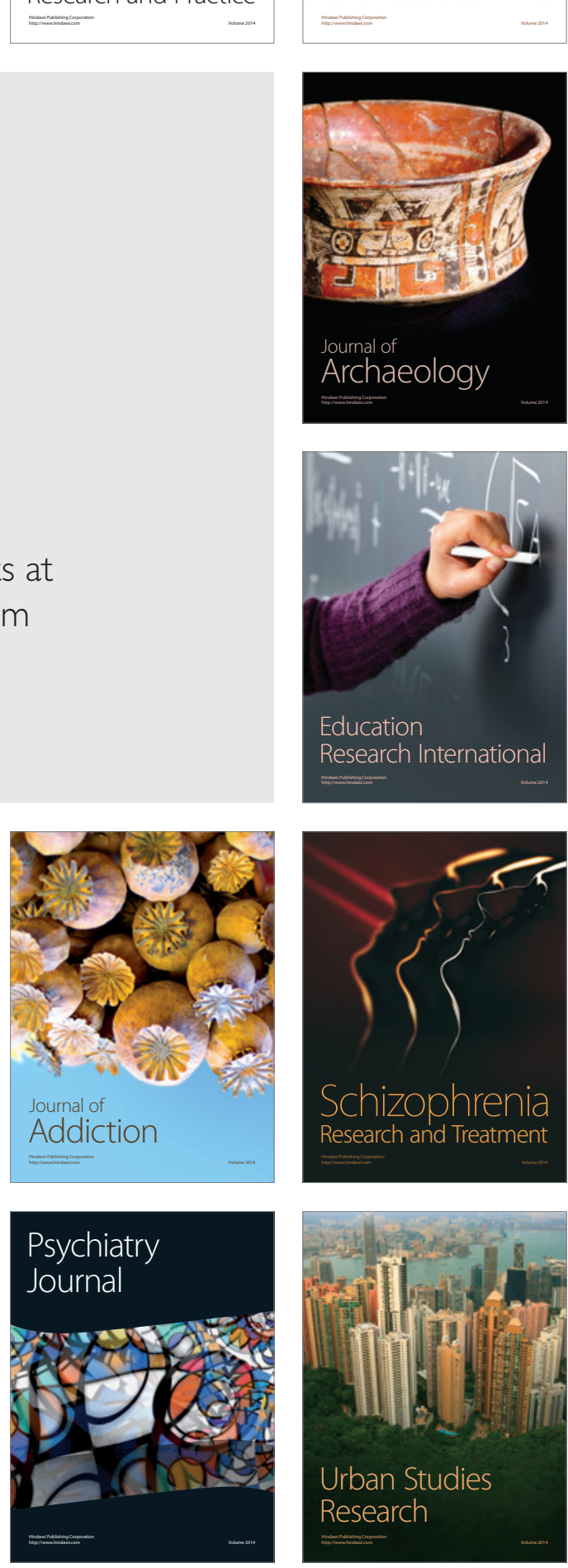